\title{
Reduced SMAD2/3 activation independently predicts increased depth of human cutaneous squamous cell carcinoma
}

\author{
Aidan M. Rose ${ }^{1,2}$, Lindsay C. Spender ${ }^{1}$, Christopher Stephen $^{2}$, Alastair Mitchell ${ }^{3}$, \\ William Rickaby ${ }^{4}$, Susan Bray ${ }^{5}$, Alan T. Evans ${ }^{6}$, Jasbani Dayal $^{1}$, Karin J. Purdie ${ }^{7}$, \\ Catherine A. Harwood ${ }^{7}$, Charlotte M. Proby ${ }^{1}$, Irene M. Leigh ${ }^{1,7}$, Philip J. Coates ${ }^{5,8}$ \\ and Gareth J. Inman ${ }^{1}$ \\ ${ }^{1}$ Division of Cancer Research, School of Medicine, University of Dundee, Ninewells Hospital and Medical School, Dundee, \\ Scotland, DD1 9SY, UK \\ ${ }^{2}$ Department of Plastic and Reconstructive Surgery, Ninewells Hospital and Medical School, NHS Tayside, Dundee, Scotland, \\ DD1 9SY, UK \\ ${ }^{3}$ Department of Dermatology, Ninewells Hospital and Medical School, NHS Tayside, Dundee, Scotland, DD1 9SY, UK \\ ${ }^{4}$ Dermatopathology Laboratory, St. John's Institute of Dermatology, St.Thomas' Hospital, London, SE1 7EH, UK \\ ${ }^{5}$ Tayside Tissue Bank, Ninewells Hospital and Medical School, NHS Tayside, Dundee, Scotland, DD1 9SY, UK \\ ${ }^{6}$ Department of Pathology, Ninewells Hospital and Medical School, NHS Tayside, Dundee, Scotland, DD1 9SY, UK \\ ${ }^{7}$ Centre for Cell Biology and Cutaneous Research, Barts and the London School of Medicine and Dentistry, Queen Mary \\ University of London, London, E1 2AT, UK \\ ${ }^{8}$ Regional Centre for Applied Molecular Oncology (RECAMO), Masaryk Memorial Cancer Institute, Brno, 656 53, Czech \\ Republic \\ Correspondence to: Gareth J. Inman, email: g.j.inman@dundee.ac.uk \\ Keywords: TGF- $\beta$; IHC; SMAD; carcinoma; FFPE \\ Received: August 01, 2017 Accepted: February 10, 2018 Epub: February 22, 2018 Published: March 06, 2018 \\ Copyright: Rose et al. This is an open-access article distributed under the terms of the Creative Commons Attribution License 3.0 \\ (CC BY 3.0), which permits unrestricted use, distribution, and reproduction in any medium, provided the original author and source \\ are credited.
}

\section{ABSTRACT}

The incidence of cutaneous squamous cell carcinoma (cSCC) is rising. Whilst the majority are cured surgically, aggressive metastatic CSCC carry a poor prognosis. Inactivating mutations in transforming growth factor beta (TGF- $\beta$ ) receptors have been identified amongst genetic drivers of sporadic tumours and murine models of CSCC, suggesting a tumour suppressor function for TGF- $\beta$ in normal skin. However, paradoxically, TGF- $\beta$ acts as a tumour promoter in some murine model systems. Few studies have analysed the role of TGF- $\beta$ /activin signalling in human normal skin, hyper-proliferative skin disorders and CSCC. Antibodies recognising phosphoSMAD proteins which are activated during canonical TGF- $\beta$ /activin signalling were validated for use in immunohistochemistry. A tissue microarray comprising FFPE lesional and perilesional tissue from human primary invasive cSCC $(n=238)$, cSCC in-situ $(n=2)$ and keratocanthoma $(n=9)$ were analysed in comparison with tissues from normal human scalp $(n=10)$. Phosphorylated SMAD2 and SMAD3 were detected in normal interfollicular epidermal keratinocytes and were also highly localised to inner root sheath, matrix cells and Keratin 15 positive cells. Lesional cSCC tissue had significantly reduced activated SMAD2/3 compared to perilesional tissue, consistent with a tumour suppressor role for SMAD2/3 activators in CSCC. Increased CSCC tumour thickness inversely correlated with the presence of phospho-SMADs in tumour tissue suggesting that a reduction in canonical TGF- $\beta$ /activin signalling may be associated with disease progression. 


\section{INTRODUCTION}

Cutaneous squamous cell carcinoma (cSCC) is the second most common skin cancer and one of the most common human cancers worldwide [1]. Whilst most lesions are cured surgically, a small subset of tumours are associated with a high-risk of soft tissue destruction, regional metastasis and poor prognosis [2]. Given its increasing incidence defining the molecular events that drive cSCC is an urgent research need. Mutational inactivation of TGF- $\beta$ receptors in skin stem cells has recently been identified as a genetic driver in a subset of cSCC, suggesting an important role for TGF- $\beta$ signalling in controlling skin homeostasis [3]. This observation is consistent with roles for TGF- $\beta$ signalling in the regulation of many developmental and normal cellular responses [4] including tissue homeostasis, immune responses and cell differentiation [5]. However, when the TGF- $\beta$ signalling pathway is disrupted it can also contribute to various pathological states ranging from immune disorders to fibrosis and cancer [5].

During cancer development, TGF- $\beta$ signalling may act as either tumour suppressor or tumour promoter in a cell-type and context dependent fashion [6]. This duality of function is readily demonstrated in murine models of skin cancer. The constitutive over-expression of TGF- $\beta$ ligand appears to protect supra-basal keratinocytes from TPA-induced epidermal hyperplasia, thereby impeding tumour formation via the regulation of keratinocyte proliferation and differentiation [7]. In contrast, in the same model systems and once tumours have progressed to invasive carcinoma, TGF- $\beta$ functionally switches to promote invasion and metastasis $[7,8]$. Equally discrepant are the few studies to examine mediators of TGF- $\beta$ signalling in normal human skin and cSCC tissue, which report contradictory findings related to the relevance and level of expression of TGF- $\beta$ ligands, TGF- $\beta$ receptors and SMAD transcription factors [9-11]. It remains unclear, therefore, when TGF- $\beta$ signalling might act to prevent or promote tumourigenesis in this disease.

TGF- $\beta$ /activin signalling can be monitored by detection of carboxyl-terminal phosphorylated forms of TGF- $\beta$ receptor-regulated intracellular signalling proteins (R-SMADs). Signalling is triggered when activated ligand binds to a constitutively active TGF- $\beta$ type 2 receptor (TGFBR2) at the cell membrane [12]. TGF$\beta$ :TGFBR2 complex then recruits and activates the TGF- $\beta$ type 1 receptor (TGFBR1) [13] which then activates the canonical SMAD transcription factors, SMAD2 and SMAD3, via C-terminal phosphorylation $\left(\mathrm{PO}_{4}^{-}\right)$at serines 465/467 and 433/435, respectively [14]. Activin signalling also induces C-terminal phosphorylation of SMAD2 and SMAD3 but via ACVR1B and ACVR2A/ACVR2B type 1 and type 2 receptors, respectively. Once phosphorylated, $\mathrm{PO}_{4}$-SMAD2 and $\mathrm{PO}_{4}-\mathrm{SMAD} 3$ form a hetero-trimeric complex with the co-operative SMAD4, and translocate to the nucleus [15]. Within the nucleus the SMAD complexes, along with other transcriptional cofactors, regulate the transcriptional activation or repression of target genes [16].

In order to better understand the role of TGF- $\beta /$ activin signalling in human skin tumours (hereafter referred to as TGF- $\beta$ signalling for simplicity), we characterise the expression of nuclear $\mathrm{PO}_{4}-\mathrm{SMAD} 2$ and $\mathrm{PO}_{4}$-SMAD3 as markers of endogenous canonical TGF- $\beta$ signalling activity within normal human skin and primary human cSCC samples. Overall, a reduction in endogenous $\mathrm{PO}_{4}$-SMAD2/3 levels were identified in $\mathrm{cSCC}$ tumours when compared to peri-lesional skin, supporting a tumour suppressor functional role for TGF- $\beta$ /activin in squamous skin cancers. Further statistical analysis of $\mathrm{PO}_{4}^{-}$ SMAD2/3 levels and their association with pathological features of cSCC demonstrate that increasing tumour depth (a known risk factor for nodal metastasis and poor prognosis) independently predicts a reduction in canonical TGF- $\beta$ signalling activity. These findings suggest that a detectable reduction in $\mathrm{PO}_{4}$-SMAD2/3 levels within a primary tumour may be biologically associated with disease progression.

\section{RESULTS}

\section{Validation of antibodies for IHC analysis}

Antibodies specific for C-terminal phosphorylated forms of SMAD proteins (see supplementary methods) were validated initially for use in immunohistochemistry (IHC) on formalin-fixed paraffin embedded (FFPE) human tissue. The human cSCC cell line SCCIC4 [17] was treated in vitro with exogenous TGF- $\beta 1$ ligand and/ or the Activin-Like Kinase 4 (ALK4)/TGFBR1(ALK5)/ ALK7 inhibitor, SB-431542 to induce or inhibit TGF- $\beta$ signalling, respectively [18]. Western blot analysis of cell lysates confirmed active upregulation of C-terminal phosphorylation in SMAD2 and SMAD3 following treatment with TGF- $\beta 1$ ligand (Figure $1 \mathrm{~A}$ ). $\mathrm{PO}_{4}$-SMAD2 and $\mathrm{PO}_{4}$-SMAD3 expression was either undetectable or reduced to below basal levels in the presence of the TGFBR1 inhibitor SB-431542 (Figure 1A). Parallel cell samples were embedded in agarose gel pellets and processed for IHC staining. FFPE SB-431542 treated SCCIC4 cells were negative for nuclear $\mathrm{PO}_{4}-\mathrm{SMAD} 2$ and $\mathrm{PO}_{4}-\mathrm{SMAD} 3$ staining. In contrast, strongly positive nuclear staining was detected in TGF- $\beta 1$ treated cells (Figure 1B), validating both antibodies for IHC on FFPE human tissue.

\section{Endogenous TGF- $\beta$ signalling activity in normal human skin}

The level and distribution of $\mathrm{PO}_{4}-\mathrm{SMAD} 2$ and $\mathrm{PO}_{4}^{-}$ SMAD3 in sections from a panel of 10 normal human 
scalp skin samples were then analysed by IHC within two skin regions, the inter-follicular epidermis (IFE) and the hair follicles (HF). Immuno-reactivity was examined and quantified by four independent scorers using the histoscore method [19] (Supplementary Methods and Supplementary Figure 1). Positive nuclear $\mathrm{PO}_{4}-\mathrm{SMAD} 2$ staining was consistently identified in both IFE (mean histoscore 118 +/- 9.3 s.d.) and HF (mean histoscore 119.7 +/- 14.8 s.d) (Figure 2A-2B). Histoscores for $\mathrm{PO}_{4}-\mathrm{SMAD} 3 \mathrm{IHC}$ were lower in the IFE (mean histoscore 77.1 +/- 14.2 s.d) which is consistent with lower levels of total SMAD3 than total SMAD2 being detectable in isolated normal skin epidermis (Supplementary Figure 2). $\mathrm{PO}_{4}-\mathrm{SMAD} 3$ histoscores in adjacent HF (mean histoscore 126.8 +/- 23.8 s.d) (Figure 2A-2B) were almost double the histoscores for IFE tissue.

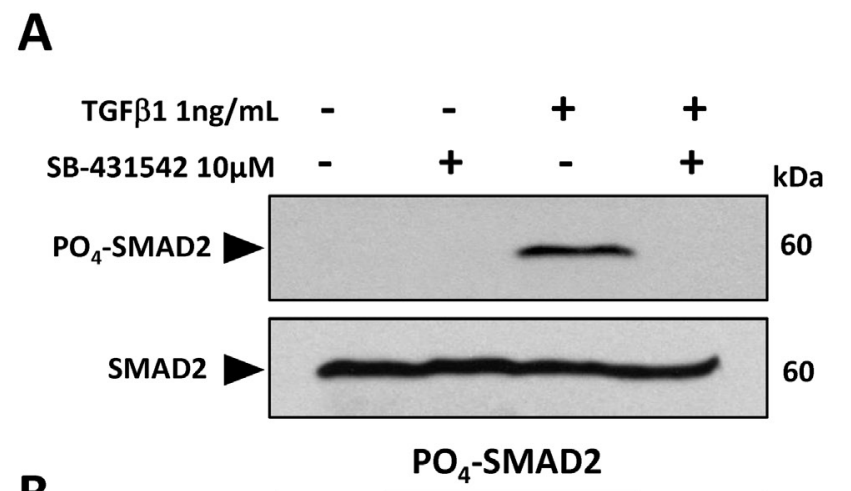

B

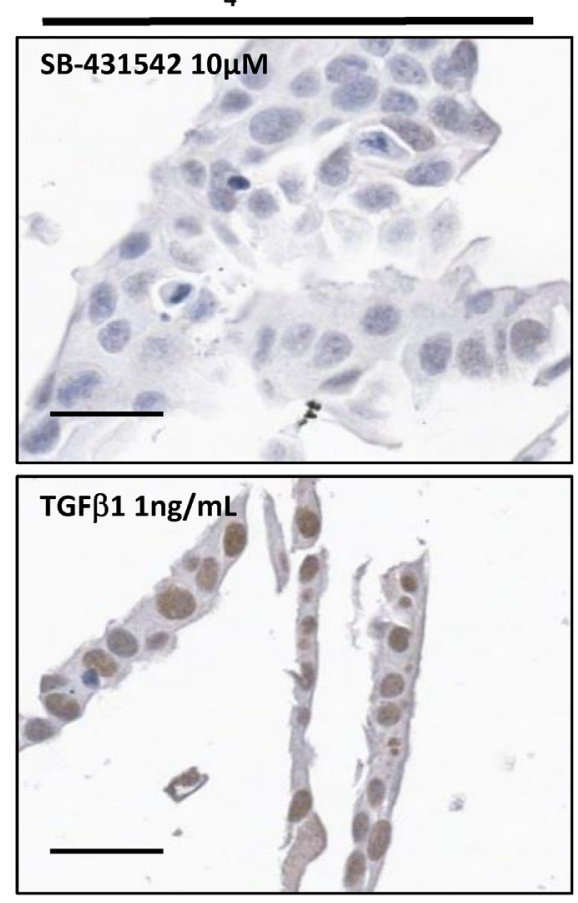

High levels of both $\mathrm{PO}_{4}-\mathrm{SMAD} 2$ and $\mathrm{PO}_{4}-\mathrm{SMAD} 3$ immuno-reactivity were also detected in the inner root sheath and hair follicle matrix (Supplementary Figure 3A$3 \mathrm{~B})$. The matrix is particularly rich in highly proliferative matrix transit amplifying (MTA) cells during anagen, which are active intermediates of quiescent hair follicle bulge (HFB) stem cells [20]. We tested whether the HFB stem cells may represent a site of active endogenous TGF- $\beta$ signalling. Human HFB stem cells are known to express KERATIN 15 (K15) [21] and richly populate the lower portion of the hair follicle during late catagen and telogen [22]. Serial sections of specimens, stained for both K15 and phosphorylated SMAD proteins (Figure 3), were screened specifically for late catagen and telogen hair follicles which appeared strongly positive for K15
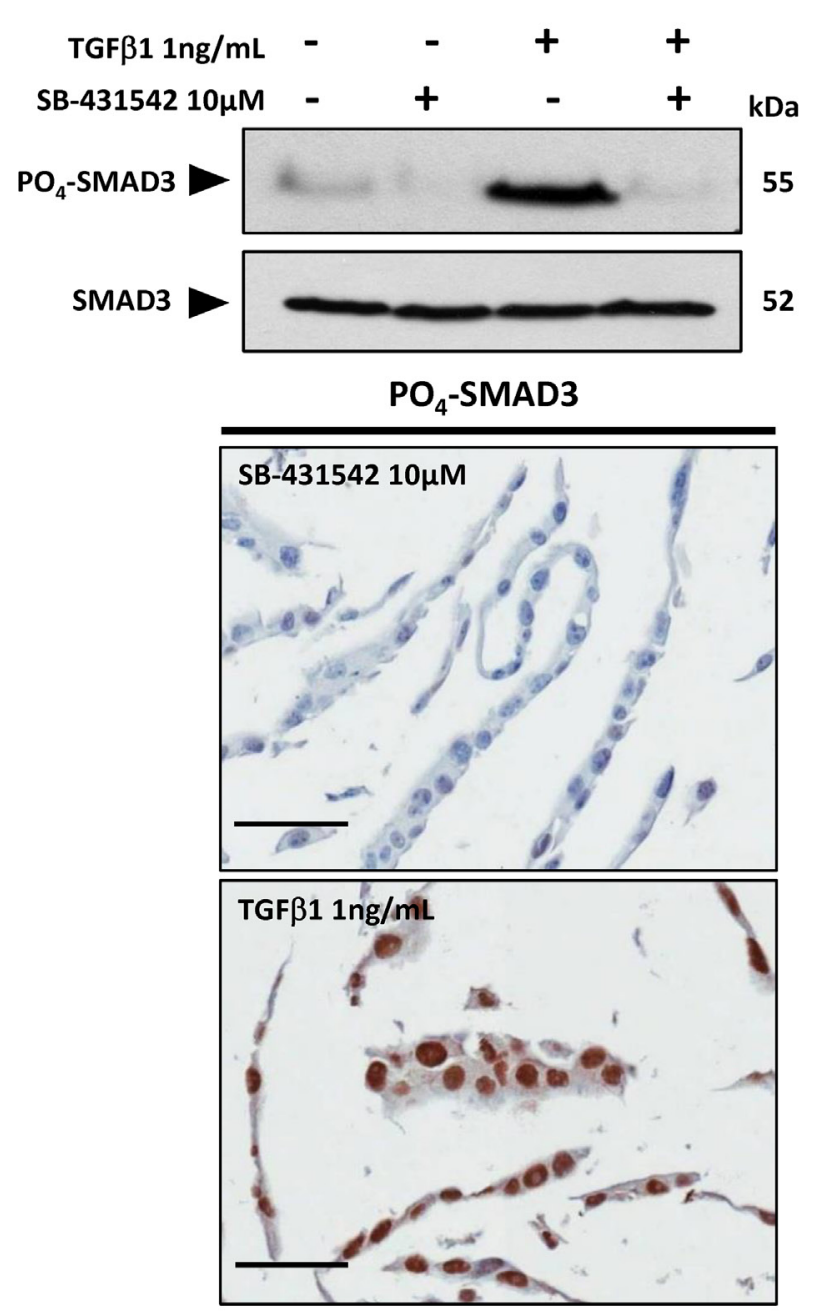

Figure 1: Validation of $\mathrm{PO}_{4}-\mathrm{SMAD} 2$ (Ser 465/467) and $\mathrm{PO}_{4}-\mathrm{SMAD3}$ (Ser 433/435) antibodies for immunohistochemistry. SCCIC4 cells were pre-treated with $10 \mu \mathrm{M}$ TGFBR1 (ALK5) kinase inhibitor SB-431542 or DMSO vehicle control followed by addition of either $1 \mathrm{ng} / \mathrm{mL}$ TGF- $\beta 1$ or vehicle control $(4 \mathrm{mM} \mathrm{HCl})$ for 1 hour as indicated. (A) Cell lysates were analysed by SDS-PAGE and western blotting using $\mathrm{PO}_{4}$-SMAD2, SMAD2, $\mathrm{PO}_{4}$-SMAD3 and SMAD3 specific antibodies as indicated. (B) Parallel cell samples treated with either TGF- $\beta 1$ (positive samples) or SB-431542 (negative samples) as described above were pelleted into agarose and embedded into paraffin wax for IHC. Representative digital images (x20 magnification, Aperio Imagescope) are shown. Scale bars $=50 \mu \mathrm{M}$. 
immuno-reactivity. K15 expression consistently colocalised with $\mathrm{PO}_{4}-\mathrm{SMAD} 3$ expression in $\mathrm{HF}$ at these stages (Figure 3).

Further sites of weak endogenous TGF- $\beta$ signalling within the dermis included blood vessel walls and adjacent clusters of eccrine glands (Supplementary Figure
3). These findings were confirmed by the site-specific nature of the staining and co-localisation between $\mathrm{PO}_{4}-$ SMAD expression and the endothelial cell marker CD31 (Supplementary Figure 4A), indicating that endogenous TGF- $\beta$ signalling may also be active in skin blood vessel walls. There was no correlation between $\mathrm{PO}_{4}^{-}$
A
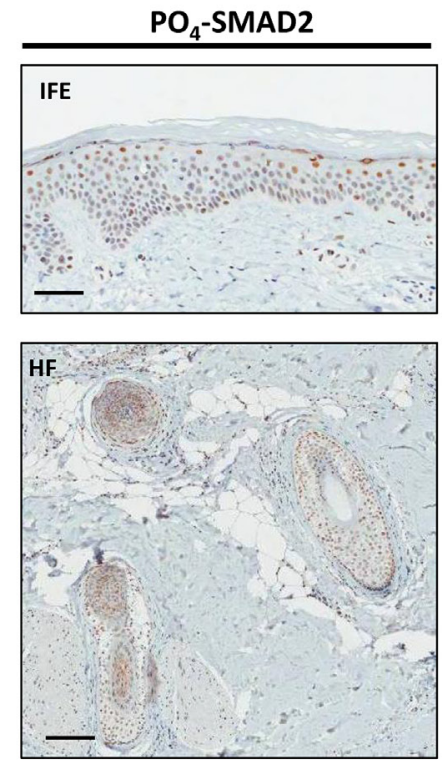
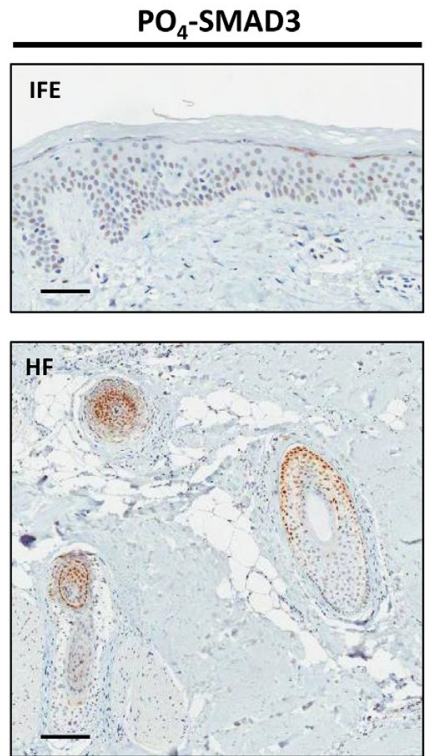

B

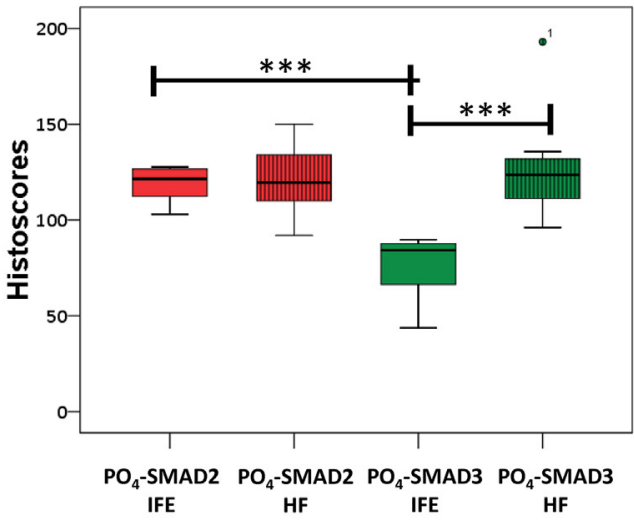

Figure 2: Endogenous TGF- $\beta$ signalling in the interfollicular epidermis and hair follicle. (A) Representative IHC images of normal human scalp skin stained with anti- $\mathrm{PO}_{4}-\mathrm{SMAD}$ antibodies as indicated. IFE $=$ Interfollicular epidermis. $\mathrm{HF}=\mathrm{Transverse}$ sections through hair follicles within dermis. (B) Box and whisker plots comparing IFE and HF histoscores for normal human scalp skin samples $(\mathrm{n}=10)$ stained with indicated antibodies. ${ }^{* * *}=\mathrm{p}<0.001$ (Student $t$-test). Scale bars $=200 \mu \mathrm{m}$.
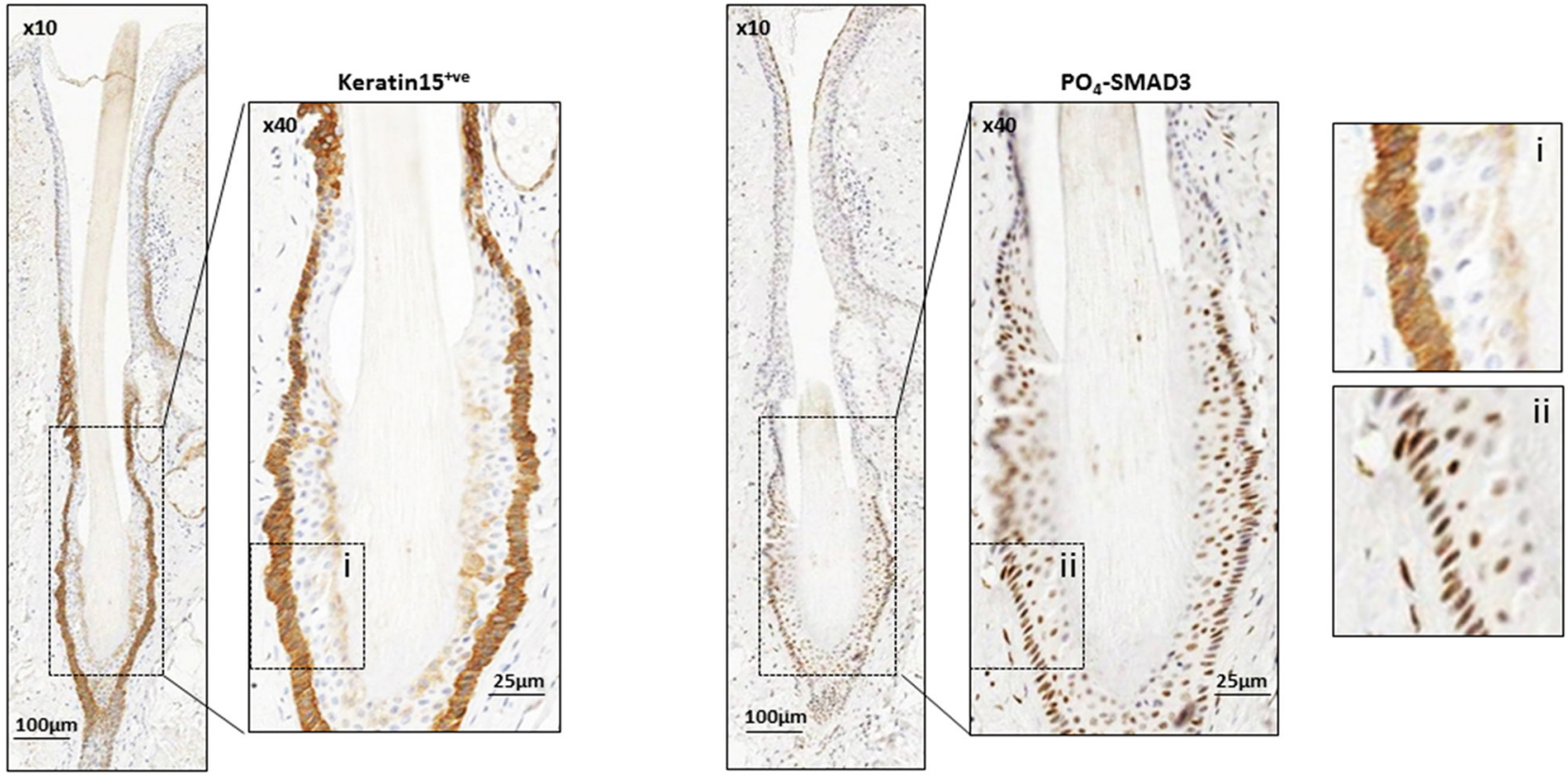

Figure 3: Endogenous TGF- $\beta$ signalling in Keratin 15 positive hair follicle bulge stem cells. Representative images of IHC of normal human scalp skin cut in serial section and stained with human bulge stem cell marker Keratin 15 (K15) and PO-SMAD3, as indicated. Enlarged sections of Keratin 15 (i) and $\mathrm{PO}_{4}$-SMAD3 (ii) stained hair bulge are shown for comparison. Magnification and scale bars as marked. 
SMAD expression and the activated fibroblast marker, $\alpha$-smooth muscle actin ( $\alpha$-SMA) (Supplementary Figure 4B). This data indicates that in normal human epidermis, endogenous canonical TGF- $\beta$ signalling exists at two sites, the IFE and the HF. Within the HF, high level activated SMAD expression appears to be present within the cellular compartments of the inner root sheath and the hair follicle matrix during anagen and K15 positive cells including the HFB stem cells during telogen stage of the hair follicle cycle.

\section{$\mathrm{PO}_{4}$-SMAD2 and $\mathrm{PO}_{4}$-SMAD3 levels are reduced in invasive tumours compared to perilesional tissue}

Next, a tissue microarray (TMA) of 249 primary squamo-proliferative lesions was examined. Of the 249 samples, 230 primary cutaneous lesions were represented by more than one informative tissue core and so were included in the final histoscore analysis. Of the 230 lesions scored, $97.8 \%$ were primary cSCC $(n=225)$ and $2.2 \%$ were KA $(n=5) .77 \%$ of the lesions were excised from sun-exposed sites of the head and neck (177/230), 73.9\% from male patients (170/230) and $63 \%$ from patients over 80 years old (145/230) (Table 1). The TMA was immuno-stained for $\mathrm{PO}_{4}$ SMAD2 and $\mathrm{PO}_{4}-\mathrm{SMAD} 3$. Overall, a significant reduction in active nuclear $\mathrm{PO}_{4}-\mathrm{SMAD} 2$ and $\mathrm{PO}_{4}$ SMAD3 staining was detected in invasive tumours when compared to site matched perilesional tissue (Figure 4). This finding indicates that impaired canonical TGF- $\beta$ signalling activity represents a common feature of human primary invasive cSCC.

Clinical and pathological variables pertinent to cSCC tumour staging [23] were then examined for association with $\mathrm{PO}_{4}-\mathrm{SMAD} 2$ or $\mathrm{PO}_{4}$-SMAD3 histoscores (Table 1 and Supplementary Figures 5-6). Statistical analysis of variance (ANOVA; significant values $p=<$ 0.05 ) revealed no significant differences in mean $\mathrm{PO}_{4}$ SMAD2 or $\mathrm{PO}_{4}$-SMAD3 histoscores analysed by patient sex, patient age, tumour pathological type (Table 1), tumour grade (Table 1 and Supplementary Figure 6A), tumour site (Table 1 and Supplementary Figure 5), the presence of peri-neural invasion (PNI) (Table 1 and Supplementary Figure 6B) or Clark level of invasion (Table 1 and Supplementary Figure 6C).

There was a significant reduction in mean $\mathrm{PO}_{4}-$ SMAD2 histoscores seen in larger diameter tumours ( $\geq 20 \mathrm{~mm}$ versus $<20 \mathrm{~mm}$ ) (Table 1 and Figure 5B, ANOVA; $p=0.013$ ) and a significant reduction in mean $\mathrm{PO}_{4}$-SMAD3 histoscores seen in tumours invading beyond subcutaneous fat (Table 1 and Figure 5C, ANOVA; $p=0.002$ ). There were also significant reductions in mean $\mathrm{PO}_{4}-\mathrm{SMAD} 2$ and $\mathrm{PO}_{4}$-SMAD3 histoscores detected in thick tumours $(\geq 4 \mathrm{~mm}$ versus $<4 \mathrm{~mm}$ ) (Table 1 and Figure 5A, ANOVA; $p=0.01$ and $\mathrm{p}=0.006$, respectively).

\section{Reduced $\mathrm{PO}_{4}-\mathrm{SMAD2}$ and $\mathrm{PO}_{4}$-SMAD3 levels correlate with large and thick invasive tumours}

To investigate in more detail the potential association between $\mathrm{PO}_{4}$-SMAD histoscores and high-risk cSCC (defined as Breslow tumour depth $\geq 4 \mathrm{~mm}$, tumour diameter $\geq 20 \mathrm{~mm}$ and invasion beyond subcutaneous fat), the data was re-analysed for significant correlations using Spearmann's rank correlation co-efficient (C.C) (Table 2). High-risk tumour depths $(\geq 4 \mathrm{~mm})$ demonstrated a highly significant negative dependence on both $\mathrm{PO}_{4}-\mathrm{SMAD} 2$ (Table 2, C.C -0.214; $\mathrm{p}=0.001$ ) and $\mathrm{PO}_{4}$-SMAD3 (Table 2, C.C -0.200; $\mathrm{p}=0.002$ ) (Supplementary Figures 7A and 8) histoscores, suggesting a correlation between thicker tumours and lower SMAD2/3 phosphorylation. A subtle but significant negative dependence was also detected between higher maximum diameter tumours and $\mathrm{PO}_{4}$ SMAD2 histoscores (Table 2, C.C -0.167; $\mathrm{p}=0.011$, Supplementary Figure 7B). Consolidating these findings, lower levels of $\mathrm{PO}_{4}$-SMAD3 correlated with tumour invasion beyond the depth of subcutaneous fat (Table 2, C.C -0.187; $\mathrm{p}=0.005$, Supplementary Figure 7C).

\section{Higher tumour depth independently predicts lower endogenous TGF- $\beta$ signalling activity}

Next, a binary logistic regression analysis was performed, using the binary outcome $\mathrm{PO}_{4}-\mathrm{SMAD} 2 / \mathrm{PO}_{4}$ SMAD3 "off" (negative) (=1) and $\mathrm{PO}_{4}-\mathrm{SMAD} 2 / \mathrm{PO}_{4}-$ SMAD3 "on" (positive) $(=0)$ as the dependent variable (Table 3). The cut-off used for detecting $\mathrm{PO}_{4}-\mathrm{SMAD} 2 /$ $\mathrm{PO}_{4}$-SMAD3 “off” was determined as a tumour histoscore of less than the $25^{\text {th }}$ percentile of the mean in both $\mathrm{PO}_{4}$ SMAD2 and $\mathrm{PO}_{4}-\mathrm{SMAD} 3$ staining. This analysis identified tumour depth as the only significant independent predictor of low $\mathrm{PO}_{4}$-SMAD expression (Table 3, Wald $($ Chi-squared $)=7.447 ; \mathrm{p}=0.006 ; \operatorname{Exp}(\mathrm{B})=1.127,95 \%$ C.I 1.034-1.227), indicating that for each unit increase in tumour depth $(\mathrm{mm})$, the odds of a tumour expressing a histoscore (for both $\mathrm{PO}_{4}-\mathrm{SMAD} 2$ and $\mathrm{PO}_{4}-\mathrm{SMAD} 3$ ) at levels below the $25^{\text {th }}$ percentile of the mean increased by $12.7 \%$ (Table $\left.3,\left(1.127^{*} 100\right)-100\right)$ - with a $95 \%$ C.I of $3.4 \%-22.7 \%$ ). This analysis further strengthens the hypothesis that TGF- $\beta$ signalling is likely to be acting primarily as a tumour suppressor in human primary cSCC and that impairment in canonical TGF- $\beta$ signalling may be advantageous for tumour cell growth and invasion.

\section{DISCUSSION}

\section{Detecting endogenous TGF- $\beta$ activity in normal human skin}

TGF- $\beta$ plays vital homeostatic roles in normal skin and during skin injury repair, but some data from models of skin carcinogenesis are contradictory. The 


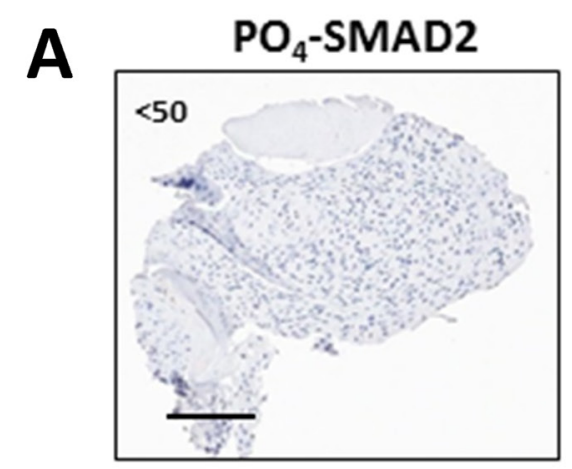

\section{$\mathrm{PO}_{4}$-SMAD3}
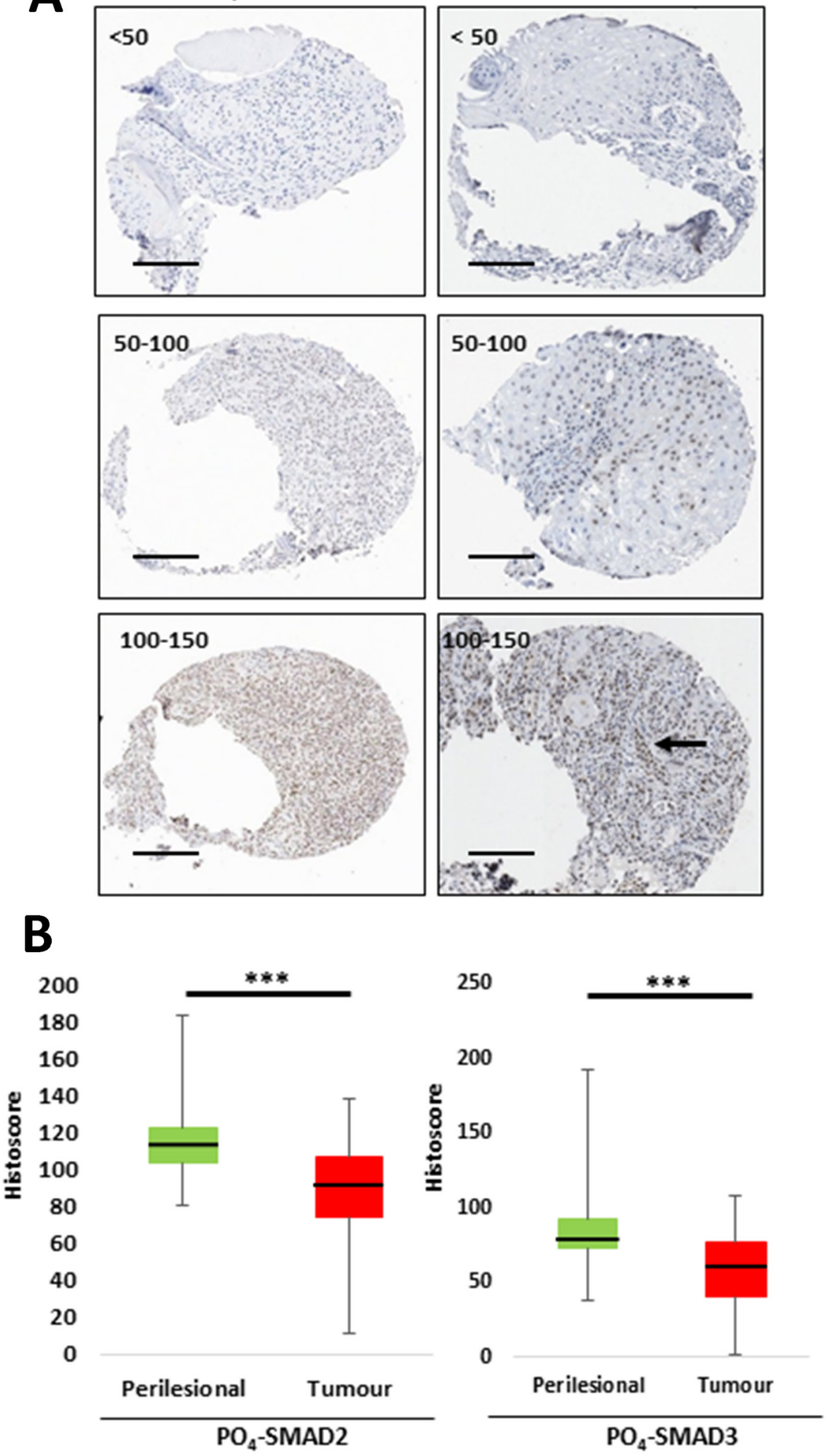

Figure 4: Active endogenous TGF- $\beta$ signalling is significantly reduced in invasive cSCC compared to perilesional tissue. (A) Representative images of tumour cores from TMA at 10-fold magnification, demonstrating varying degrees of histoscores from low $(<50)$ to high $(100-150)$ for $\mathrm{PO}_{4}-\mathrm{SMAD}_{2}$ and $\mathrm{PO}_{4}-\mathrm{SMAD} 3$ immunostaining as labelled. Tumour-Stroma heterogeneity labelled by arrow. (B) Graphical representative of mean histoscores for perilesional tissue (green) and tumour (red) across the whole TMA for $\mathrm{PO}_{4}$ SMAD2 and $\mathrm{PO}_{4}$-SMAD3 immunostaining as labelled. ${ }^{* * *} \mathrm{p}=<0.001$ (Wilcoxon matched pairs test). Scale bar $=200 \mu \mathrm{m}$. 
Table 1: Mean tumour $\mathrm{PO}_{4}$-SMAD histoscores for patient and tumour variables with analysis of variance

\begin{tabular}{|c|c|c|c|c|c|c|c|c|c|}
\hline \multirow[b]{2}{*}{ Variable } & \multirow[b]{2}{*}{ Category } & \multirow[b]{2}{*}{ Number } & \multirow[b]{2}{*}{ Percent } & \multicolumn{3}{|c|}{$\begin{array}{l}\mathrm{PO}_{4} \text {-SMAD2 Tumour } \\
\text { HISTOSCORES }\end{array}$} & \multicolumn{3}{|c|}{$\begin{array}{c}\mathrm{PO}_{4} \text {-SMAD3 Tumour } \\
\text { HISTOSCORES }\end{array}$} \\
\hline & & & & Mean & S.D & Sig. (ANOVA) & Mean & S.D & Sig. (ANOVA) \\
\hline \multirow[t]{2}{*}{ Sex } & Male & 170 & 73.9 & 89.06 & 24.36 & & 57.73 & 23.14 & \\
\hline & Female & 60 & 26.1 & 86.58 & 23.48 & 0.497 & 60.88 & 25.38 & 0.377 \\
\hline \multirow[t]{6}{*}{ Site } & High-risk H\&N & 66 & 28.7 & 90.33 & 21.92 & & 61.83 & 22.98 & \\
\hline & Low-risk H\&N & 111 & 48.3 & 86.95 & 24.39 & & 56.72 & 23.71 & \\
\hline & Torso & 5 & 2.2 & 72.29 & 23.99 & & 44.67 & 24.08 & \\
\hline & Upper limb & 38 & 16.5 & 92.05 & 26.94 & & 59.79 & 25.53 & \\
\hline & Lower limb & 9 & 3.9 & 94.92 & 21.69 & & 62.84 & 19.79 & \\
\hline & Perineal & 1 & 0.4 & 109.13 & - & 0.442 & 29.14 & - & 0.645 \\
\hline \multirow[t]{2}{*}{ Grade } & $<$ Poorly Diff & 152 & 66.1 & 88.69 & 23.75 & & 59.34 & 23.74 & \\
\hline & $\geq$ Poorly Diff & 78 & 33.9 & 87.88 & 24.94 & 0.81 & 57.01 & 23.75 & 0.481 \\
\hline \multirow[t]{2}{*}{$\begin{array}{l}\text { Tumour } \\
\text { Depth }\end{array}$} & $<4 \mathrm{~mm}$ & 115 & 50 & 92.50 & 24.64 & & 62.83 & 22.77 & \\
\hline & $\geq 4 \mathrm{~mm}$ & 115 & 50 & 84.33 & 22.96 & 0.01 & 54.28 & 23.99 & 0.006 \\
\hline \multirow[t]{2}{*}{ Clark Level } & $<$ IV & 21 & 9.1 & 85.82 & 25.54 & & 57.11 & 23.42 & \\
\hline & $\geq \mathbf{I V}$ & 209 & 90.9 & 88.68 & 24.01 & 0.605 & 58.69 & 23.8 & 0.771 \\
\hline \multirow[t]{2}{*}{$\begin{array}{l}\text { Perineural } \\
\text { Invasion }\end{array}$} & Absent & 214 & 93 & 88.38 & 24.48 & & 58.76 & 23.95 & \\
\hline & Present & 16 & 7 & 88.98 & 18.94 & 0.922 & 55.79 & 21.03 & 0.631 \\
\hline \multirow[t]{2}{*}{$\begin{array}{l}\text { Maximum } \\
\text { Diameter }\end{array}$} & $<20 \mathrm{~mm}$ & 168 & 73 & 90.81 & 23.36 & & 59.97 & 23.58 & \\
\hline & $\geq 20 \mathrm{~mm}$ & 62 & 27 & 81.92 & 25.09 & 0.013 & 54.7 & 23.88 & 0.135 \\
\hline \multirow[t]{2}{*}{$\begin{array}{l}\text { Depth of } \\
\text { Invasion }\end{array}$} & $\begin{array}{c}\text { Up to } \\
\text { subcutaneous fat }\end{array}$ & 205 & 89.1 & 89.01 & 24.29 & & 60.2 & 23.2 & \\
\hline & $\begin{array}{c}\text { Beyond } \\
\text { subcutaneous fat }\end{array}$ & 25 & 10.9 & 83.5 & 22.41 & 0.282 & 45 & 24.07 & 0.002 \\
\hline
\end{tabular}

S.D $=$ Standard Deviation, H\&N = Sun-exposed head and neck, Clark Level IV = Invasion into the reticular dermis, $\mathrm{ANOVA}=$ One-way analysis of variance (significant $p$-value $=<0.05$ ).

ligand appears to be consistently expressed throughout normal human epidermis $[9,11,24]$ and its constitutive over-expression protects murine supra-basal keratinocytes from DMBA/TPA-induced epidermal hyperplasia [7, 25]. This protection appears to coincide with the induction of TGF- $\beta$ 's obligate type 2 receptor (TGFBR2), indicating a vital role for TGF- $\beta$ signalling in skin homeostasis. TGFBR2 is also strongly expressed in normal human IFE $[9,11]$. However, expression of active TGF- $\beta$ in the basal layer is also associated with inflammation and hyperproliferation [26].

Investigating the role of TGF- $\beta$ superfamily ligands in skin homeostasis and disease has been problematic because of a lack of suitable reagents. Some researchers have relied on the detection of the TGF- $\beta$ latencyassociated peptide, produced as part of the TGF- $\beta$ latent precursor, as a surrogate marker of TGF- $\beta$ ligand expression in tissues [7]. Since, in this form, TGF- $\beta$ ligand is an inactive precursor protein, the biological relevance of IHC detection of ligand, associated peptides or receptor levels as tumour markers of endogenous signalling activity is debatable [27]. The formation of ligand-receptor complex is known to drive rapid depletion of receptors from the cell surface, which rate-limits the activation of down-stream TGF- $\beta$ signalling [28]. Thus, in this study, neither the expression of TGF- $\beta$ superfamily ligands or 
TGFBR2 were assessed because commercially available antibodies could not be validated for IHC on FFPE tissue to the same rigorous validation standards that we achieved for the anti- $\mathrm{PO}_{4}-\mathrm{SMAD} 2$ and $\mathrm{PO}_{4}-\mathrm{SMAD} 3$ antibodies. Nuclear $\mathrm{PO}_{4}-\mathrm{SMAD} 2$ expression was consistently observed within the human epidermis in this study and in others [9, 11, 29]. C-terminal phosphorylation of the R-SMAD's is known to be sufficient for their nuclear accumulation and transcriptional activity [4]. As such, levels of phosphorylated R-SMAD's can be correlated directly with TGF- $\beta$ signal strength and transcriptional responses [30]. The selection of nuclear $\mathrm{PO}_{4}-\mathrm{SMAD} 2 / 3$ expression was therefore considered appropriate as a direct marker of endogenous TGF- $\beta$ signalling activity in human skin. At present though, we cannot formally identify which ligand has potential tumour suppressor function since other TGF- $\beta$ superfamily members can also activate canonical $\mathrm{PO}_{4}-\mathrm{SMAD} 2$ and 3 via their own distinct serine threonine receptor kinase complexes including Activin, Nodal, and GDF-8 (myostatin) [31]. Activins are of particular interest, as they appear to share many of the regulatory characteristics of TGF- $\beta$ in keratinocytes [32].
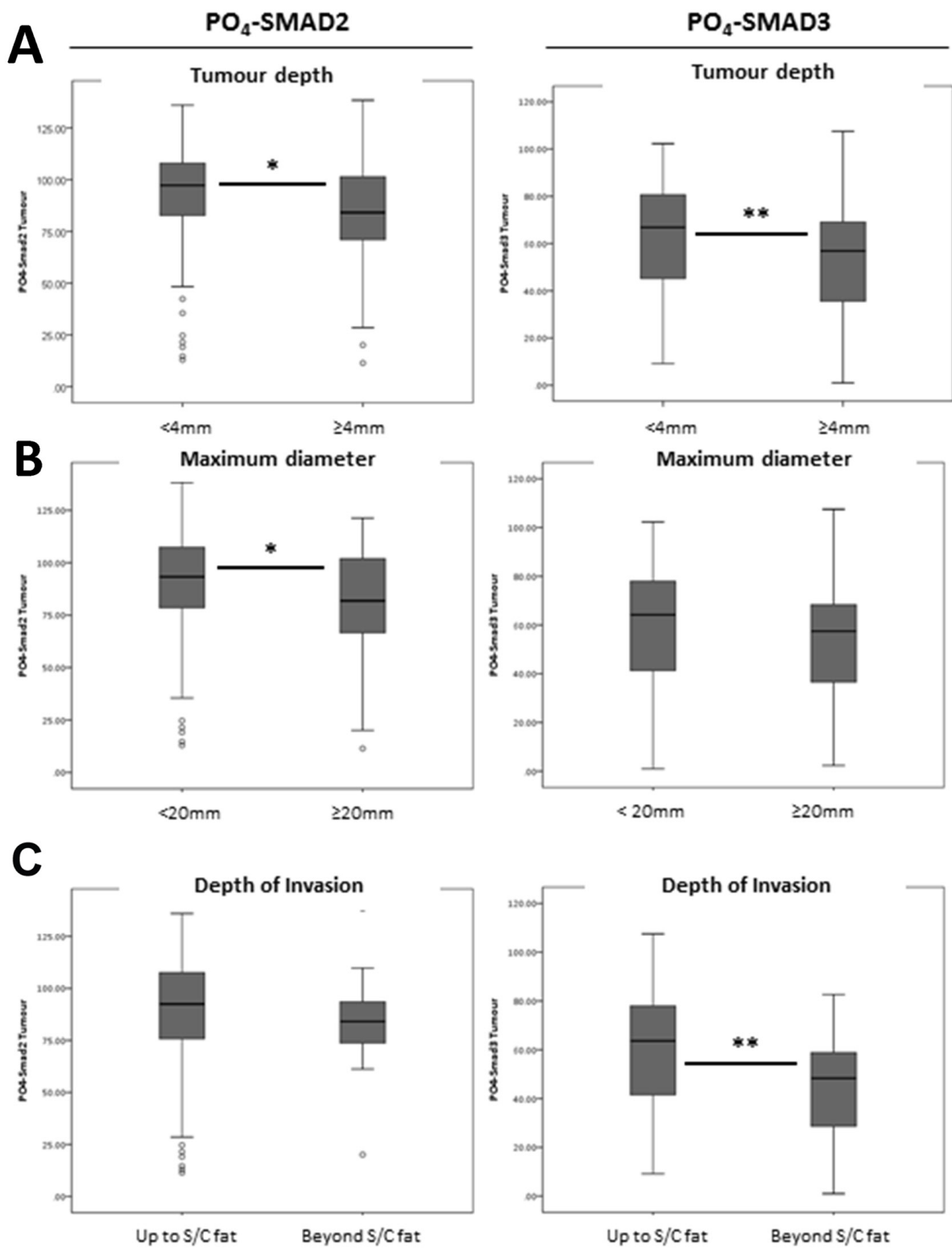

Figure 5: TMA histoscores identify a significant association between mean nuclear R-Smad expression and cSCC tumour depth, diameter and pathological depth of invasion. (A) Nuclear $\mathrm{PO}_{4}-\mathrm{SMAD} 2$ and $\mathrm{PO}_{4}$-SMAD3 activity by tumour depth, defined as $<4 \mathrm{~mm}$ and $\geq 4 \mathrm{~mm}$. (B) Nuclear $\mathrm{PO}_{4}-\mathrm{SMAD} 2$ and $\mathrm{PO}_{4}$-SMAD3 activity by maximum tumour diameter, defined as $<20 \mathrm{~mm}$ or $\geq 20 \mathrm{~mm}$. (C) Nuclear $\mathrm{PO}_{4}-\mathrm{SMAD} 2$ and $\mathrm{PO}_{4}-\mathrm{SMAD} 3$ activity by pathological depth of invasion. Grouped as invasion up to subcutaneous fat and invasion beyond subcutaneous fat. Analysis of Variance (ANOVA) Sig ${ }^{*} p=<0.05,{ }^{* *} \mathrm{p}=<0.01$. 
Table 2: Statistical correlations between cSCC perilesional and tumour TGF- $\beta$ activity and selected "High-Risk" cSCC pathological variables

\begin{tabular}{|c|c|c|c|c|}
\hline & & & $\mathrm{PO}_{4}$-SMAD2 & $\mathrm{PO}_{4}$-SMAD3 \\
\hline \multirow[t]{10}{*}{ Spearman's } & $\mathrm{PO}_{4}$-SMAD2 & C.C & & $.366^{* * * *}$ \\
\hline & & Sig. (2-tailed) & . & .000 \\
\hline & $\mathrm{PO}_{4}$-SMAD3 & C.C & $.366^{* * *}$ & \\
\hline & & Sig. (2-tailed) & .000 & . \\
\hline & Depth $>4 \mathrm{~mm}$ & C.C & $-.214^{* *}$ & $-.200^{* *}$ \\
\hline & & Sig. (2-tailed) & .001 & .002 \\
\hline & Diameter $>\mathbf{2 0} \mathrm{mm}$ & C.C & $-.167^{*}$ & -.115 \\
\hline & & Sig. (2-tailed) & .011 & .081 \\
\hline & $\begin{array}{c}\text { Beyond } \\
\text { subcutaneous fat }\end{array}$ & C.C & -.101 & $-.187^{* *}$ \\
\hline & & Sig. (2-tailed) & .125 & .005 \\
\hline
\end{tabular}

C.C $=$ Correlation co-efficient, Sig. $=$ Significance, $N=$ Number, $\mathrm{S} / \mathrm{C}=$ Subcutaneous.

${ }^{* * *}$ Correlation is significant at $\mathrm{p}=<0.001$ level (2-tailed). ${ }^{* *}$ Correlation is significant at $\mathrm{p}=<0.01$ level (2-tailed).

${ }^{*}$ Correlation is significant at $\mathrm{p}=<0.05$ level (2-tailed).

Activin ligands are expressed mainly in the dermis, but their obligatory type 1 receptor (ACVR1B) is expressed in the epidermis, indicating that they could act in a paracrine fashion to regulate keratinocyte proliferation [33]. Coincidentally, Activin-A preferentially induces $\mathrm{PO}_{4}$-SMAD3 expression in $\mathrm{HaCaT}$ human keratinocyte cells [34], thus other TGF- $\beta$ superfamily members may also contribute to SMAD activation in human skin.

In keeping with TGF- $\beta$-mediated regulation of keratinocyte proliferation and differentiation, the level of nuclear $\mathrm{PO}_{4}$-SMAD2 expression was consistently high within the IFE, but, IFE $\mathrm{PO}_{4}$-SMAD3 histoscores were significantly lower overall. This apparent discrepancy could reflect a differential expression of total SMAD2 and SMAD3 proteins within the IFE. We could not assess total protein levels of nonphosphorylated SMADs in FFPE sections as, again, the specificity of these antibodies could not be confirmed and there is a paucity of published data on total SMAD2 or SMAD3 protein expression in normal human skin samples. A single study described expression of total SMAD2 and SMAD3 in the upper epidermal layers and hair follicles, but reported no obvious differences in levels [35]. However, our analysis of isolated epidermis from four normal skin donors, suggests that the levels of total detectable SMAD3 are lower than SMAD2 which could account for the differential detection of phosphorylated SMAD proteins seen in this study. It is also possible that there is differential activation $\left(\mathrm{PO}_{4}^{-}\right.$ ) of SMAD proteins within the epidermis but little is known about the potential biological mechanisms, or the affects, of any selective activation of SMAD2 versus SMAD3 [36].
Immunostaining of human HF's suggests that both SMAD2- and SMAD3-dependent TGF- $\beta$ signalling are active in these specialised structures. Interestingly, this active signalling was detected at seemingly dichotomous points in the hair follicle cycle, localised to the proliferative MTA cells of anagen (growth phase) follicles, but also the Keratin 15 positive HFB stem cells of telogen (resting phase) follicles. Endogenous TGF- $\beta 1$ is known to suppress proliferation and induce apoptosis of MTA cells of the hair follicle bulb, driving the transition from anagen to catagen phases of the hair follicle cycle $[37,38]$. This transition is characterised by a decline in proliferation and the differentiation of MTA cells in the hair follicle bulb. The MTA cells appeared rich in $\mathrm{PO}_{4}^{-}$ SMAD2 and $\mathrm{PO}_{4}$-SMAD3 expression in this study, suggesting that endogenous SMAD-dependent TGF- $\beta 1$ driven signalling may be an integral regulator of human MTA cells. The expression of phosphorylated R-SMADs was also consistently localised to the HFB stem cells during telogen, consistent with recent murine studies [39]. This expression appears to be driven by the secretion of TGF- $\beta 2$ ligand from adjacent DP cells, which in turn negatively regulates inhibitory BMP signalling, resulting in the activation of telogen HFB stem cells which drive hair follicle regeneration and a transition from telogen to anagen [39]. Our data are consistent with similar regulatory functions of TGF- $\beta$ in human hair follicles.

\section{TGF- $\beta$ signalling in human $\mathrm{cSCC}$}

High-throughput genomic analyses of sporadic human invasive cSCC have demonstrated the presence of frequent mutations in TGF- $\beta$ receptors $[3,40,41]$, 
Table 3: Binary logistic regression model identifies tumour depth as an independent predictor of lower cSCC R-Smad activity

\begin{tabular}{lccccc}
\hline Variable & DF & $\mathbf{X}^{\mathbf{2}}$ (Wald) & $\mathbf{P}(<\mathbf{0 . 0 5})$ & $\mathbf{R . R}$ & $\mathbf{9 5 \%}$ CI \\
\hline Depth & 1 & 7.447 & 0.006 & 1.127 & $1.034-1.227$ \\
Poorly diff & 1 & 3.125 & 0.077 & & \\
Site = Lower limb & 1 & 1.168 & 0.280 & & \\
Diameter & - & 1.107 & 0.293 & & \\
Invasion beyond fat & 1 & 0.739 & 0.390 & & \\
Site = Torso & 1 & 0.629 & 0.428 & \\
Clark level $\geq$ IV & 1 & 0.140 & 0.708 & \\
Site = Upper limb & 1 & 0.114 & 0.736 & \\
Site = High-risk H\&N & 1 & 0.82 & 0.774 & \\
PNI & 1 & 0.48 & 0.827 & & \\
Site = Low-risk H\&N & 1 & 0.019 & 0.889 & & \\
\hline
\end{tabular}

Binary outcome $=$ TGF $-\beta$ Signalling "off" * $(0=$ No, $1=$ Yes $)$.

${ }^{*} \leq 25^{\text {th }}$ Percentile of the mean $\left(\mathrm{PO}_{4}-\mathrm{SMAD} 2=\leq 76, \mathrm{PO}_{4}-\mathrm{SMAD} 3=\leq 41\right) . \mathrm{B}=$ Co-efficients, $\mathrm{S} . \mathrm{E}=$ Standard error of co-efficients, Wald $=$ Wald chi-squared value. $\mathrm{df}=$ degree of freedom, Sig. $=2$-tailed $p$-value for testing null hypothesis. $\operatorname{Exp}(B)=$ Exponentiation of co-efficients (Odds ratios), C.I $=$ Confidence intervals. H\&N $=$ Sun-exposed head and neck, Clark Level IV = Invasion into the reticular dermis, PNI = Perineural invasion.

indicating that TGF- $\beta$ signalling is likely to act as a key tumour suppressor, and that mutational inactivation of this pathway may be a key driving event in tumour formation [3]. This proposed role is supported by evidence from three human "models" of squamous skin tumours: a clear genotype-phenotype correlation between germline inactivating TGFBR1 mutations and families suffering from multiple self-healing squamous epithelioma (MSSE) [42], the presence of TGFBR1 mutations in sorafenibinduced skin tumours [43] and clinical cancer trial data reporting spontaneous cSCC arising as a side-effect of systemic treatment with the pan-TGF- $\beta$ ligand antibody, GC1008 [44].

Our current study, reporting an analysis of possibly the largest published TMA of primary human cSCC to date, supports the idea that loss of canonical TGF $\beta$ pathway signalling is associated with $\mathrm{cSCC}$ disease progression. Overall, despite some contradictory evidence, data from alternative IHC studies in human disease appear consistent with our finding of a trend towards attenuation of TGF- $\beta$ signalling [9-11, 35]. Whilst Harradine et al reported elevated SMAD activation, their analysis discussed only a direct comparison of mediators of TGF- $\beta$ signalling between tumours from organ transplant recipients and sporadic tumours from the non-transplant recipient population [11]. The same data, when comparing tumour progression from normal to invasive carcinoma, irrespective of tumour host, suggests an overall reduction in $\mathrm{PO}_{4}-\mathrm{SMAD} 2$ staining intensities [11]. This current study provides the added assurances that we compare lesional with peri-lesional uninvolved tissue and that the antibodies used were carefully validated prior to use.

The histoscore scoring method averages variation in immunostaining across tissue cores, therefore, the extent of possible heterogeneity of TGF- $\beta$ signalling throughout the tumour tissue was not directly addressed in this study. A more in-depth examination of cell or site-specific TGF- $\beta$ signalling activity in cSCC (e.g active signalling localised to the leading invasive edges of tumour) might reveal further clues as to where the likely biological roles for active TGF- $\beta$ signalling lie.

No previous study has examined correlations between known "high-risk" pathological features of cSCC tumours and the degree of active TGF- $\beta$ family signalling. A consistent association and significant correlation between low $\mathrm{PO}_{4}-\mathrm{SMAD} 2 / 3$ expression and thick tumours $(\geq 4 \mathrm{~mm}$ depth) was identified. Importantly, the strength of this association was such that increasing tumour depth remained an independent predictor of low tumour $\mathrm{PO}_{4}^{-}$ SMAD expression when accounting for all other "highrisk" variables. This correlation provides further evidence that TGF- $\beta$ signalling appears to be acting primarily as a tumour suppressor in $\mathrm{CSCC}$ and suggests that a reduction in active TGF- $\beta$ signalling may provide a significant growth advantage for affected tumour cells - as recently demonstrated in-vitro using primary human cSCC cell lines carrying mutant TGFBR2 and lacking canonical signalling potential [3]. As tumour thickness represents a pathological marker of invasion, it also indicates that active canonical SMAD signalling may not preclude 
features of tumour progression, such as tumour invasion, in human cSCC.

Recent studies in mice suggest that HF and IFE stem cells are epigenetically primed differentially to undergo epithelial to mesenchymal transition during tumourigenesis, with HF derived cells more likely to acquire a canonical TGF- $\beta$ /SMAD2-driven EMT phenotype than IFE derived cells [45]. Thus, the epigenetic state of the cancer cells of origin may have a significant impact on the outcome of TGF- $\beta$ mediated signalling. Since EMT is reported to be required for SCC dissemination [46], how these observations relate to tumourigenic events in human skin warrants further investigation. This study indicates that reduced canonical signalling via the SMADs correlates with high risk phenotypic changes, however, as the TGF- $\beta$ pathway can also activate non-SMAD pathways such as the Mitogen Activated Protein (MAP) kinase pathway, Rholike GTPase pathways (RhoA) and Phosphatidylinositol3-kinase (PI3K)/Protein Kinase B (AKT) pathways [47], it is possible that, as TGF- $\beta$ 's SMAD-dependent tumour suppressor arm is impaired, pro-tumourigenic non-SMAD pathways dominate to drive invasion and metastasis [48]. Interestingly, the detection of EMT markers in SCC tumours correlates with upregulation of phosphorylated forms of active AKT, suggesting that signalling through AKT may be involved in EMT and could be targeted to suppress invasion [46]. It is unknown, however, whether AKT activation in SCC is TGF- $\beta$ receptor dependent. Further analysis of the TMA for expression of both SMAD-dependent and nonSMAD dependent target genes and their correlation with $\mathrm{PO}_{4}$-SMAD expression may shed further light on whether such cross-talk has a role in human cSCC tumour tissue.

Significant tumour thickness (or depth of invasion) is a known risk factor for nodal metastasis (NM) in human cSCC $[49,50]$. Our findings lead to the hypothesis that a reduction in signalling via SMADs may also correlate with increased risk of NM. This was not tested directly as the number of patients re-presenting with NM was too low to justify the analysis at this current time $(n=2 / 249$; data not shown). Such analysis was also compounded by two patient factors: the first being that most patients presenting with cSCC were elderly ( $63 \%$ over 80 yrs old in this study) which limits possible follow-up times and the likelihood of disease recurrence prior to mortality unrelated to cSCC disease progression; and secondly, the fact that the majority of the patients in this study presented with SCC between 2012 and 2014 and, to date, the followup times are too short to accumulate sufficient numbers of NM for analysis. There is an established link between loss of TGF- $\beta$ signalling and the mode of tumour invasion, for example, murine and rat in-vivo breast carcinoma models reveal that blockade of TGF- $\beta$ signalling drives cohesive (or collective) tumour cell migration and invasion [51, 52]. Importantly, cells invading collectively appear primed for lymphatic rather than blood-borne spread [51] in both breast cancer and HNSCC models [52, 53]. If this process could also be demonstrated in the context of cSCC, it would suggest that a reduction in active TGF- $\beta$ signalling could prime cSCC tumour cells for collective tumour cell invasion and potentially drive their natural predilection for lymphatic spread. Given this, further investigation into the loss of endogenous $\mathrm{PO}_{4}$-SMAD activity as a biomarker for aggressive disease in cSCC is warranted.

\section{MATERIALS AND METHODS}

This study was conducted according to the Declaration of Helsinki Principles. Ethical approval was obtained from the local NHS Tayside Research Ethics Committee Research Ethics Number: NHS REC 08.S1401.69 - "The Molecular Pathogenesis of Non-melanoma Skin Cancers". All patients participating in this study provided written, informed consent. Normal scalp skin was only obtained as redundant "dog-ear" tissue following minor plastic surgery procedures for benign lesions. Lesional and perilesional tissue from a total of 249 patients presenting to the Ninewells Hospital Plastic Surgery and Dermatology Departments, between 2007 and 2013, were included in this study (see Table 1 for patient/lesion details). In total, 249 sporadic primary squamo-proliferative skin lesions from immunocompetent patients (one tumour per patient) were identified and included in the array, including: 238 primary invasive cSCC, 2 cSCC in-situ and 9 keratoacanthoma. Of these samples, 230 were represented by more than one independent tissue core on the TMA (92\%). Of these 230 tumours, 150 (65\%) had more than one sufficient adjacent peri-lesional skin core for analysis.

\section{Optimisation of immunohistochemistry (IHC) conditions}

Primary human cSCC cell lines, SCCIC4 and SCCIC18 were cultured in standard conditions using $\mathrm{RM}^{+}$ media (10\% FCS) as previously described [54]. Adherent sub-confluent monolayers of at least $5 \times 10^{6}$ cells in 75 $\mathrm{cm}^{2}$ tissue culture flasks were treated with either vehicle control (4 mM HCl, $1 \mathrm{mg} / \mathrm{mL}$ BSA; DMSO, 1:1000 dilution), $1 \mathrm{ng} / \mathrm{mL}$ TGF- $\beta 1$ (positive sample) or $10 \mu \mathrm{M}$ TGFBR1 kinase inhibitor SB-431542 (negative sample) [18] for 1 hour. Cells were fixed in formalin, the cell pellets re-suspended in agarose and then embedded in paraffin prior to sectioning and IHC staining as previously described [55].

\section{Western blotting}

Cells were lysed in SDS lysis buffer and analysed by SDS-polyacrylamide gel electrophoresis and western blotting. Bound immunocomplexes were detected by enhanced chemiluminescence (ECL; Amersham). All primary and secondary antibodies used are described in supplementary information. 


\section{IHC of FFPE tissue sections}

Normal skin samples were fixed immediately in $4 \%$ paraformaldehyde and processed using a standard automated histology processor prior to embedding into paraffin wax blocks. For all IHC staining four-micron thick sections were cut onto Polysine-coated slides and air dried at room temperature prior to de-paraffinisation and rehydration via a graded alcohol series. Citrate buffer antigen retrieval and DAKO autostaining (Ely, Cambridgeshire, UK) using Vectastain $^{\circledR} \mathrm{ABC}$ kits (Vector Labs, Burlingame, CA, USA) was performed as per manufacturer's instructions and as described in supplementary methods. The antibodies used for IHC are described in supplementary methods.

\section{Tissue microarray (TMA)}

Lesions were identified by the retrospective collection of pathology reports containing minimum datasets for primary cSCC [56]. H\&E slides were then reviewed, marked and used as templates for coring from their corresponding paraffin blocks using a manual tissue arrayer. A maximum of six $x 1 \mathrm{~mm}$ cores at least $3 \mathrm{~mm}$ thick per specimen were targeted for inclusion. Cores were constructed in a grid design, facilitated by TMA Designer $^{\mathrm{R}} 2$ software. Matched lesional and peri-lesional samples were arranged in random order.

\section{Image processing and digital image analysis}

All stained sections were scanned using the Aperio $\AA$ Scanscope XT slide scanner (Aperio ${ }^{\circledR}$ Technologies, Inc., Vista, CA) and visualised digitally online using the Aperio e-slide manager via the Tayside Tissue Bank: https:// aperio-sql.tissuebank.dundee.ac.uk/.

\section{Quantification of immunostaining and statistical analyses}

All tissue sections were scored for protein expression levels via a simplified Histoscore method [19] as described in Supplementary methods. To account for heterogeneity of staining between tumour and stroma, only positive tumour cells and skin keratinocytes were scored. Scoring was undertaken remotely by four trained independent investigators blinded to the TMA structure and original pathology reports. Statistical analysis included paired samples $T$-test (Sig. $\mathrm{p}<0.05$ ), non-parametric correlations between staining intensities and clinic-pathological variables (Spearmans-Rho - Sig. $\mathrm{p}<0.05$ ) and binary logistic regression. All statistics were performed using SPSS v20 (IBM).

\section{Abbreviations}

cSCC, cutaneous squamous cell carcinoma. IHC, immunohistochemistry. FFPE, formalin-fixed paraffin embedded. TGF- $\beta$, transforming growth factor beta. MTA, matrix transit amplifying, TMA, tissue microarray. IFE, inter-follicular epidermis. HF, hair follicles. ALK, activinlike kinase.

\section{Author contributions}

Participated in research design: Rose, Proby, Leigh, Inman Purdie.

Conducted experiments: Rose, Bray, Coates, Dayal,

Performed data/TMA analysis: Rose, Bray (constructed), Mitchell, Stephens, Rickaby, Evans, Inman

Wrote or contributed to the writing of the manuscript: Rose, Spender, Proby and Inman.

\section{ACKNOWLEDGMENTS}

We thank all patients who generously donated tissue to the Tayside Biorepository, Dundee for research. We acknowledge staff at the Department of Pathology, Ninewells Hospital, the Chief Scientist Office, NHS Scotland and the Tayside Biorepository, Dundee. We would particularly like to acknowledge and thank the Tayside Biorepository staff for their contributions to acquiring paraffin embedded and fresh tissue samples, in particular Sally Chalmers (S.C) and Kate McLean (K.McL) for contributions to patient consent, tissue acquisition and storage (S.C) and construction of the tissue microarray (K.McL and S.B). Additionally, we would like to thank Dr Simon A Ogston, Lecturer in Medical Statistics, School of Medicine, University of Dundee, for counsel on statistical data analysis.

\section{CONFLICTS OF INTEREST}

We declare no conflicts of interest.

\section{FUNDING}

A.M.R. was supported by Cancer Research UK [Clinical PhD Fellowship/Centre grant (A12976) and Postdoctoral Research Bursary for Clinical Trainees (A22912)] and the Academy of Medical Sciences [Starter Grant for Clinical Lecturers (SGL015\1022)]. G.J.I., K.J.P, C.A.H, I.M.L. and C.M.P. were supported by a Cancer Research UK programme grant (A13044) and a European Research Council grant (250170). L.C.S. was supported by Worldwide Cancer Research grant (11-0788).

\section{REFERENCES}

1. Stern RS. Prevalence of a history of skin cancer in 2007: results of an incidence-based model. Arch Dermatol. 2010; 146:279-282. 
2. Karia PS, Jambusaria-Pahlajani A, Harrington DP, Murphy GF, Qureshi AA, Schmults CD. Evaluation of american joint committee on cancer, international union against cancer, and brigham and women's hospital tumor staging for cutaneous squamous cell carcinoma. J Clin Oncol. 2014; $32: 327-34$.

3. Cammareri P, Rose AM, Vincent DF, Wang J, Nagano A, Libertini S, Ridgway RA, Athineos D, Coates PJ, McHugh A, Pourreyron C, Dayal JHS, Larsson J, et al. Inactivation of TGF $\beta$ receptors in stem cells drives cutaneous squamous cell carcinoma. Nature communications. 2016; 7:12493.

4. Shi Y, Massague J. Mechanisms of tgf-beta signaling from cell membrane to the nucleus. Cell. 2003; 113:685-700.

5. Massague J. Tgfbeta in cancer. Cell. 2008; 134:215-230.

6. Inman GJ. Switching TGFbeta from a tumor suppressor to a tumor promoter. Curr Opin Genet Dev. 2011; 21:93-99.

7. Cui W, Fowlis DJ, Bryson S, Duffie E, Ireland H, Balmain A, Akhurst RJ. TGFbetal inhibits the formation of benign skin tumors, but enhances progression to invasive spindle carcinomas in transgenic mice. Cell. 1996; 86:531-542.

8. Perez-Lorenzo R, Markell LM, Hogan KA, Yuspa SH, Glick AB. Transforming growth factor betal enhances tumor promotion in mouse skin carcinogenesis. Carcinogenesis. 2010; 31:1116-1123.

9. Han G, Lu SL, Li AG, He W, Corless CL, Kulesz-Martin M, Wang XJ. Distinct mechanisms of tgf-beta1-mediated epithelial-to-mesenchymal transition and metastasis during skin carcinogenesis. J Clin Invest. 2005; 115:1714-1723.

10. Hoot KE, Lighthall J, Han G, Lu SL, Li A, Ju W, KuleszMartin M, Bottinger E, Wang XJ. Keratinocyte-specific Smad2 ablation results in increased epithelial-mesenchymal transition during skin cancer formation and progression. J Clin Invest. 2008; 118:2722-32.

11. Harradine KA, Ridd K, Saunier EF, Clermont FF, PerezLosada J, Moore DH, Epstein EH Jr, Bastian BC, Akhurst RJ. Elevated cutaneous smad activation associates with enhanced skin tumor susceptibility in organ transplant recipients. Clin Cancer Res. 2009; 15:5101-5107.

12. Wrana JL, Attisano L, Wieser R, Ventura F, Massague J. Mechanism of activation of the TGF-[beta] receptor. Nature. 1994; 370:341-347.

13. Wieser R, Wrana JL, Massagué J. GS domain mutations that constitutively activate $\mathrm{T}$ beta R-I, the downstream signaling component in the TGF-beta receptor complex. The EMBO Journal. 1995; 14:2199-2208.

14. Wu JW, Hu M, Chai J, Seoane J, Huse M, Li C, Rigotti DJ, Kyin S, Muir TW, Fairman R, Massagué J, Shi Y. Crystal structure of a phosphorylated Smad2. Recognition of phosphoserine by the MH2 domain and insights on Smad function in TGF- $\beta$ signaling. Mol Cell. 2001; 8:1277-89.

15. $\mathrm{Xu} \mathrm{L}$, Chen YG, Massague J. The nuclear import function of smad 2 is masked by SARA and unmasked by TGFbetadependent phosphorylation. Nat Cell Biol. 2000; 2:559-562.
16. Massague J. TGF[beta] signalling in context. Nat Rev Mol Cell Biol. 2012; 13:616-630.

17. South AP, Purdie KJ, Watt SA, Haldenby S, den Breems NY, Dimon M, Arron ST, Kluk MJ, Aster JC, McHugh A, Xue DJ, Dayal JH, Robinson KS, et al. NOTCH1 mutations occur early during cutaneous squamous cell carcinogenesis. J Invest Dermatol. 2014; 134:2630-2638.

18. Inman GJ, Nicolas FJ, Callahan JF, Harling JD, Gaster LM, Reith AD, Laping NJ, Hill CS. SB-431542 is a potent and specific inhibitor of transforming growth factor-beta superfamily type i activin receptor-like kinase (ALK) receptors ALK4, ALK5, and ALK7. Mol Pharmacol. 2002; 62:65-74.

19. Nenutil R, Smardova J, Pavlova S, Hanzelkova Z, Muller P, Fabian P, Hrstka R, Janotova P, Radina M, Lane DP, Coates PJ, Vojtesek B. Discriminating functional and non-functional p53 in human tumours by p53 and MDM2 immunohistochemistry. J Pathol. 2005; 207:251-259.

20. Mesa KR, Rompolas P, Greco V. The Dynamic Duo: Niche/ Stem Cell Interdependency. Stem Cell Reports. 2015; 4:961-966.

21. Purba TS, Haslam IS, Poblet E, Jimenez F, Gandarillas A, Izeta A, Paus R. Human epithelial hair follicle stem cells and their progeny: current state of knowledge, the widening gap in translational research and future challenges. Bioessays. 2014; 36:513-525.

22. Ito M, Kizawa K, Hamada K, Cotsarelis G. Hair follicle stem cells in the lower bulge form the secondary germ, a biochemically distinct but functionally equivalent progenitor cell population, at the termination of catagen. Differentiation. 2004; 72:548-557.

23. Karia PS, Jambusaria-Pahlajani A, Harrington DP, Murphy GF, Qureshi AA, Schmults CD. Evaluation of American Joint Committee on Cancer, International Union Against Cancer, and Brigham and Women's Hospital tumor staging for cutaneous squamous cell carcinoma. J Clin Oncol. 2014; $32: 327-334$.

24. Quan T, He T, Kang S, Voorhees JJ, Fisher GJ. Ultraviolet irradiation alters transforming growth factor beta/smad pathway in human skin in vivo. J Invest Dermatol. 2002; 119:499-506.

25. Wang XJ, Liefer KM, Tsai S, O'Malley BW, Roop DR. Development of gene-switch transgenic mice that inducibly express transforming growth factor beta1 in the epidermis. Proc Natl Acad Sci USA. 1999; 96:8483-8488.

26. Liu X, Alexander V, Vijayachandra K, Bhogte E, Diamond I, Glick A. Conditional epidermal expression of TGFbeta 1 blocks neonatal lethality but causes a reversible hyperplasia and alopecia. Proc Natl Acad Sci USA. 2001; 98:9139-9144.

27. Shi M, Zhu J, Wang R, Chen X, Mi L, Walz T, Springer TA. Latent Tgf-[bgr] structure and activation. Nature. 2011; 474:343-349. 
28. Vizan P, Miller DS, Gori I, Das D, Schmierer B, Hill CS. Controlling long-term signaling: receptor dynamics determine attenuation and refractory behavior of the TGFbeta pathway. Sci Signal. 2013; 6:ra106.

29. Xie W, Bharathy S, Kim D, Haffty BG, Rimm DL, Reiss M. Frequent alterations of smad signaling in human head and neck squamous cell carcinomas: a tissue microarray analysis. Oncol Res. 2003; 14:61-73.

30. Schmierer B, Hill CS. Tgfbeta-smad signal transduction: molecular specificity and functional flexibility. Nat Rev Mol Cell Biol. 2007; 8:970-982.

31. Hinck AP. Structural studies of the TGF- $\beta$ s and their receptors - insights into evolution of the TGF- $\beta$ superfamily. FEBS Letters. 2012; 586:1860-1870.

32. McDowall M, Edwards NM, Jahoda CAB, Hynd PI. The role of activins and follistatins in skin and hair follicle development and function. Cytokine \& Growth Factor Reviews. 2008; 19:415-426.

33. Hubner G, Hu Q, Smola H, Werner S. Strong induction of activin expression after injury suggests an important role of activin in wound repair. Dev Biol. 1996; 173:490-498.

34. Shimizu A, Kato M, Nakao A, Imamura T, ten Dijke P, Heldin CH, Kawabata M, Shimada S, Miyazono K. Identification of receptors and smad proteins involved in activin signalling in a human epidermal keratinocyte cell line. Genes Cells. 1998; 3:125-134.

35. Lange D, Persson U, Wollina U, ten Dijke P, Castelli E, Heldin CH, Funa K. Expression of tgf-beta related smad proteins in human epithelial skin tumors. Int J Oncol. 1999; 14:1049-1056.

36. Brown KA, Pietenpol JA, Moses HL. A tale of two proteins: differential roles and regulation of $\operatorname{smad} 2$ and $\operatorname{smad} 3$ in TGF- $\beta$ signaling. J Cell Biochem. 2007; 101:9-33.

37. Tsuji Y, Denda S, Soma T, Raftery L, Momoi T, Hibino T. A potential suppressor of tgf-[beta] delays catagen progression in hair follicles. J Investig Dermatol Symp Proc. 2003; 8:65-68.

38. Foitzik K, Lindner G, Mueller-Roever S, Maurer M, Botchkareva N, Botchkarev V, Handjiski B, Metz M, Hibino T, Soma T, Dotto GP, Paus R. Control of murine hair follicle regression (catagen) by TGF-beta1 in vivo. FASEB J. 2000; 14:752-760.

39. Oshimori N, Fuchs E. Paracrine tgf-beta signaling counterbalances bmp-mediated repression in hair follicle stem cell activation. Cell stem cell. 2012; 10:63-75.

40. Pickering CR, Zhou JH, Lee JJ, Drummond JA, Peng SA, Saade RE, Tsai KY, Curry JL, Tetzlaff MT, Lai SY, Yu J, Muzny DM, Doddapaneni H, et al. Mutational landscape of aggressive cutaneous squamous cell carcinoma. Clin Cancer Res. 2014; 20:6582-6592.

41. Li YY, Hanna GJ, Laga AC, Haddad RI, Lorch JH, Hammerman PS. Genomic analysis of metastatic cutaneous squamous cell carcinoma. Clin Cancer Res. 2015; 21:1447-1456.
42. Goudie DR, D'Alessandro M, Merriman B, Lee H, Szeverenyi I, Avery S, O'Connor BD, Nelson SF, Coats SE, Stewart A, Christie L, Pichert G, Friedel J, et al. Multiple self-healing squamous epithelioma is caused by a diseasespecific spectrum of mutations in TGFBR1. Nat Genet. 2011; 43:365-369.

43. Arnault JP, Mateus C, Escudier B, Tomasic G, Wechsler J, Hollville E, Soria JC, Malka D, Sarasin A, Larcher M, Andre J, Kamsu-Kom N, Boussemart L, et al. Skin tumors induced by sorafenib; paradoxic RAS-RAF pathway activation and oncogenic mutations of hras, TP53, and TGFBr1. Clin Cancer Res. 2012; 18:263-272.

44. Morris JC, Tan AR, Olencki TE, Shapiro GI, Dezube BJ, Reiss M, Hsu FJ, Berzofsky JA, Lawrence DP. Phase i study of gc1008 (fresolimumab): a human anti-transforming growth factor-beta (TGF $\beta$ ) monoclonal antibody in patients with advanced malignant melanoma or renal cell carcinoma. PLoS ONE. 2014; 9:e90353.

45. Latil M, Nassar D, Beck B, Boumahdi S, Wang L, Brisebarre A, Dubois C, Nkusi E, Lenglez S, Checinska A, Vercauteren Drubbel A, Devos M, Declercq W, et al. Cell-type-specific chromatin states differentially prime squamous cell carcinoma tumor-initiating cells for epithelial to mesenchymal transition. Cell stem cell. 2017; 20:191204 e195.

46. Barrette K, Van Kelst S, Wouters J, Marasigan V, Fieuws S, Agostinis P, van den Oord J, Garmyn M. Epithelialmesenchymal transition during invasion of cutaneous squamous cell carcinoma is paralleled by AKT activation. The British journal of dermatology. 2014; 171:1014-1021.

47. Derynck R, Muthusamy BP, Saeteurn KY. Signaling pathway cooperation in tgf-beta-induced epithelialmesenchymal transition. Curr Opin Cell Biol. 2014; 31:56-66.

48. Davies M, Prime SS, Eveson JW, Price N, Ganapathy A, D'Mello A, Paterson IC. Transforming growth factor- $\beta$ enhances invasion and metastasis in Ras-transfected human malignant epidermal keratinocytes. Int J Exp Pathol. 2012; 93:148-156.

49. Brantsch KD, Meisner C, Schonfisch B, Trilling B, WehnerCaroli J, Rocken M, Breuninger H. Analysis of risk factors determining prognosis of cutaneous squamous-cell carcinoma: a prospective study. Lancet Oncol. 2008; 9:713-720.

50. Breuninger $\mathrm{H}$, Brantsch $\mathrm{K}$, Eigentler $\mathrm{T}$, Hafner $\mathrm{HM}$. Comparison and evaluation of the current staging of cutaneous carcinomas. J Dtsch Dermatol Ges. 2012; 10:579-586.

51. Giampieri S, Manning C, Hooper S, Jones L, Hill CS, Sahai E. Localised and reversible TGF $\beta$ signalling switches breast cancer cells from cohesive to single cell motility. Nature cell biology. 2009; 11:1287-1296.

52. Matise LA, Palmer TD, Ashby WJ, Nashabi A, Chytil A, Aakre M, Pickup MW, Gorska AE, Zijlstra A, Moses HL. Lack of transforming growth factor-beta signaling promotes collective cancer cell invasion through tumor-stromal crosstalk. Breast Cancer Res. 2012; 14:R98. 
53. Le Bras GF, Taylor C, Koumangoye RB, Revetta F, Loomans HA, Andl CD. TGFbeta loss activates ADAMTS-1-mediated EGF-dependent invasion in a model of esophageal cell invasion. Exp Cell Res. 2015; 330:29-42.

54. Proby CM, Purdie KJ, Sexton CJ, Purkis P, Navsaria HA, Stables JN, Leigh IM. Spontaneous keratinocyte cell lines representing early and advanced stages of malignant transformation of the epidermis. Exp Dermatol. 2000; 9:104-117.
55. Hannigan A, Smith P, Kalna G, Lo Nigro C, Orange C, O'Brien DI, Shah R, Syed N, Spender LC, Herrera B, Thurlow JK, Lattanzio L, Monteverde M, et al. Epigenetic downregulation of human disabled homolog 2 switches TGF-beta from a tumor suppressor to a tumor promoter. J Clin Invest. 2010; 120:2842-2857.

56. Slater D, Walsh M. Dataset for the histological reporting of primary invasive cutaneous squamous cell carcinoma and regional lymph nodes. The Royal College of Pathologists. 2014. 